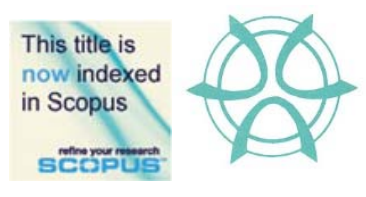

PLANNING MALAYSIA:

Journal of the Malaysian Institute of Planners

VOLUME 16 ISSUE 2 (2018), Page 334 - 344

\title{
A COMPARATIVE REVIEW OF DESIGN REQUIREMENTS FOR NATURAL SMOKE VENTILATION IN HOSPITAL BUILDINGS
}

\author{
Mohd Zaid Ab Ghani ${ }^{1}$ \& Srazali Aripin ${ }^{2}$ \\ ${ }^{1,2}$ Kulliyyah of Architecture \& Environmental Design \\ INTERNATIONAL ISLAMIC UNIVERSITY MALAYSIA
}

\begin{abstract}
Smoke is recognized as the main factor of fatality when fire occurred in a building. Thus, smoke management in the building is of paramount importance in order to achieve a tenable indoor environment in the event of fire other than ensuring passive means of escapes to the place of safety. In hospital building, where patients have limited movements, natural smoke ventilation through windows is the most common form of smoke control design. Nevertheless, inappropriate design of natural smoke ventilation through window may result to poor smoke air flow contributing to unwanted toxic gases inhaled by occupants that lead to fatalities in the event of fire. This study aims to analyse the design requirements and specifications of natural smoke ventilation system in buildings by exploring local and other prominent building regulations as well as code of practices around some countries. The study found that smoke ventilation system (natural and mechanical) is usually applied in windowless building, basement and in large open spaces. The natural smoke ventilation system employs smoke vents (gravity vents) located at a higher level in the roof or at the ceiling level. The regulations state that the size of smoke vents for effective natural smoke ventilation is in between $2 \%$ to $3 \%$ of the floor areas. Most regulations would allow openable windows for smoke ventilation in the event of fire.
\end{abstract}

Keywords: natural smoke ventilation, smoke vent, hospital, windowless 
PLANNING MALAYSIA

Journal of the Malaysia Institute of Planners (2018)

\section{INTRODUCTION}

Uncontrolled fire is one of the catastrophic accidents in hospital building that threatens the life of occupants particularly patients, staff, visitors and other users. There have been many cases in the past where uncontrolled fire in hospital had caused injuries and deaths (Kulkarni, Giri, \& Gangwal, 2016; Jalali, Asl, Mehr, Pourafzali, \& Ghasemi, 2016). In built environment, fire cases would be a huge threat to human life in a closed environment and workplace especially in public healthcare facilities (Krol, 2011; Hui, 2013; Kulkarni et al., 2016). Hospital is a place where people come to seek for treatment of various illnesses and for emergency situations. Vulnerable people like the elderly, children, and pregnant mothers, patients with physical and mental disabilities are greatly affected by the danger of fire in hospitals. They need a longer time to escape or be evacuated to safer place due to their weaknesses and mobility impairments. It has been accepted by many researchers in the field of healthcare facilities that the complexity of functions and services of hospital are due to (1) the availability of vulnerable patients, (2) the presence of potentially hazardous materials and (3) the need for the patients to be consistently assisted (Bongiovanni, Leo, Ritrovato, Santoro, \& Derrico, 2017). Therefore, safety against fire in hospital buildings is of paramount importance.

Fire safety design (passive as well as active) is an important element to protect the life of occupants during fire. It refers to fire prevention, reduction of fire and smoke spread, fire extinguishment and achieving a quick and safe exit (Kobes, Helsloot, Vries, \& Post, 2010). In the event of fire, the key hazardous product of combustion such as smoke must be controlled and ventilated, so that people are not severely exposed. The hazards of smoke are; elevated temperature, toxicity and low visibility ( $\mathrm{Li}, \mathrm{Su}, \&$ Tsai, 2016). Smoke can be a major contributor to fatalities in fire (Tancogne-Dejean \& Laclémence, 2016; Ji, Gao, Fan, \& Sun, 2013; Chan, 2004; Yatim, 2009; Strating, 2013) and smoke management system plays a significant role in maintaining safety of occupants when fire occurred in hospital building (Partridge, 2013). During fire, evacuating patients to a safe place is not only difficult but time-consuming process as well. Therefore, providing a good and sufficient smoke control system should be considered such as adopting Available Safe Egress Time (ASET) when designing hospital (AAMA, 2010).

Natural smoke ventilation by means of window design is the most common form of smoke control system in hospital buildings particularly wards. However, inappropriate design of natural smoke ventilation through window may result in poor smoke air flow contributing to unwanted toxic gases inhaled by occupants during fire.

Although a natural ventilation design can provide an interior airflow path, it may also have adverse impacts on the way how fire spread and smoke flows in the event of fire in a building (Lai, Chen, Tsai, Tsai, \& Lin, 2013). Inappropriate 
Mohd Zaid Ab Ghani \& Srazali Aripin

A Comparative Review of Design Requirements for Natural Smoke Ventilation in Hospital Buildings

natural smoke ventilation strategy (window design) in the event of a fire situation may contribute to fatalities due to stack effect (Su, Huang, Lin, \& Lin, 2014), strong wind at high level of the supertall building may accelerate the fire and smoke development (Yue, Chow, Fong, \& Kong, 2016) and promoting fire severity due to increase oxygen supply (Chen, Liu, \& Chow, 2009). Natural ventilation design has two contradictory effects on fire as it promotes fire severity by supplying oxygen and cooling the fire by dilution of smoke (Chen et al., 2009). Also, an experiment conducted by National Institute of Standards and Testing (NIST) on the impact of large openings of windows on fire has resulted in a greater Heat Release Rate (HRR) (Kerber, 2010). According to Wojciech \& Grzegorz (2017), the sole possibility for natural smoke ventilation design using windows along the parameter façade as smoke ventilators is not recommended in most buildings because it can lead to non-effective smoke ventilation. However, preliminary findings based on the literature review shows that natural smoke ventilation design (i.e. window design) has an impact on fire safety unless there are some appropriate design approaches to alleviate those effects.

Providing appropriate natural smoke ventilation design for fire safety in a hospital ward is a challenging task and requires careful consideration. Code requirements with regard to smoke exhaust system must be understood by healthcare designers in order to ensure safety of the people in hospital ward during fire. Therefore the local and prominent international regulations and code of practices on natural smoke ventilation design should be reviewed and analysed to achieve appropriate design specifications and applications for hospital buildings in order to create a tenable condition in the event of fire.

\section{FIRE ISSUES AND FIRE CASES IN HOSPITALS}

There are a number of hazards in hospitals that threaten patient safety, for example, disease infection, and delay of medical treatment, slip, electricity failure, fall, and fire (Hui, 2013). Fire in hospital buildings has claimed many lives as well as causes injury to many people (Ong \& Suleiman, 2015). In Malaysia, there were approximately 209 cases of fire occurred in hospitals and clinics between the year 2010 and the year 2016 (JBPM, 2017). The incidents often lead to serious adverse effects on the building occupants, visitors, and properties. The most catastrophic case in Malaysia was fire at Intensive Care Unit (ICU) ward in Sultanah Aminah Hospital, Johor Bharu, Malaysia. The fire broke out at 9 a.m. on 25 October 2016, where six patients were killed. The victims (four female and two male) were in-patients at Intensive Care Unit (ICU) located at the second floor of the hospital's main building. Initially, seven patients were trapped, but only six were reported perished in the blaze. Another patient was successfully rescued with $80 \%$ of his body burnt. Apart from that, two hospital staff members suffered serious injuries. It is believed that the victims died due to suffocation of the thick smoke, which rapidly spread throughout the ward. 
PLANNING MALAYSIA

Journal of the Malaysia Institute of Planners (2018)

On December 9, 2011, another massive fire occurred at Advanced Medicare and Research Institute (AMRI) Hospital, Kolkata, India. 90 people were reported choked to death (Pal \& Ghosh, 2014). The hospital was centrally air-conditioned building and it was turned-off due to the electricity failure. When fire starts, smoke began to accumulate into the hospital wards and in escape route. There were no windows in the ward except fixed glass walls for natural lighting. The hazardous smoke subsequently could not be removed from the building (Pal \& Ghosh, 2014) and patients in the wards and Intensive Care Unit (ICU) were suffocated and died due to lack of smoke control (Nagral, 2012). The fire began in the hospital basement, where highly flammable gases and liquids were improperly stored. Smoke filled up rapidly in most spaces in the hospital and the windows were locked at that time. Staff had to break the window in order to remove the thick smoke. Unfortunately, most of the people died were due to smoke inhalation.

The Required Self Egress Time (RSET) is a critical period of time that need to be considered to safeguard the life of people in the building. The RSET is the time duration taken by occupants to get to the place of safety in the event of fire before condition become untenable. Kobes et al. (2010) found that fire involving fatalities primarily occurred at night in buildings accommodated by people with disabilities, such as nursing homes, hospitals, residential and prisons. Ong and Suleiman (2015) identified mistakes and problems of fire accidents across the world in hospital building constructed from the year 1918 to the year 2013. The mistakes include lack of automatic fire protection installations, lack of law enforcement, poor planning, poor maintenance and management in fire safety, poor performance of staff, combustible material and conflict between security and fire safety. On the same note, investigation carried out by Ong and Suleiman (2015) in four public hospitals in Malaysia found that documentation issues, use of combustible and flammable materials, lack of fire safety installations, locked doors and windows due to security reasons and lack of training of hospital staff are the factors contributing to fire.

\section{THE ROLES OF NATURAL SMOKE VENTILATION DESIGN IN HOSPITAL BUILDING}

Natural smoke ventilation design has significant influence in the safety of people in a building (i.e. hospital) by: (1) extending the time available for people to escape from the building, so-named Available Safe Evacuation Time (ASET), (2) by alleviating the threat posed by smoke produced during fire; (3) reducing the fire growth by lowering down the temperature of the smoke thus limiting the radiation towards flammable materials in the building; (4) facilitating the firefighting operations in the building by reducing the amount and the temperature of smoke inside of the building (Wegrzynski \& Krajewski, 2017). 
Mohd Zaid Ab Ghani \& Srazali Aripin

A Comparative Review of Design Requirements for Natural Smoke Ventilation in Hospital Buildings

\section{A COMPARATIVE REVIEW OF REGULATIONS AND CODE OF PRACTICES ON NATURAL SMOKE VENTILATION DESIGN IN BUILDING}

\section{Uniform Building By-Laws (UBBL, 1984) and Malaysian Standard (MS 1780)}

According to the UBBL 1984, smoke ventilation system is required in a building with no window, basement and; in a large and open space building. By Laws 249 states that; "in windowless buildings, underground structures and large area factories, smoke venting facilities shall be provided for the safe use of exit". The Malaysian Building Code prescribes the natural smoke ventilation design is applied by installing high-level smoke vents located in roof or wall in order to exhaust smoke in case of fire. Clause 250 Sub-clause (2) of the UBBL 1984 reveals that; "natural draught smoke vent shall utilize roof vents or vents in walls at or near the ceiling level". As accorded by the code, the smoke vents shall be permanent openings or if they are closed, they shall be designed to be opened automatically by opening devices. The regulation also incorporates performance requirement of the smoke ventilation system that need to be satisfied as in Clause 251; "the smoke ventilation facilities are installed for the purposes of exit safety shall be adequate to prevent dangerous accumulation of smoke during the period of time necessary to evacuate the area served using available exit facilities with a margin of safety to allow for unforeseen contingencies". Where buildings with windows, smoke produced by fires may be naturally ventilated through windows' openings.

The Uniform Buildings By-Laws (Amendment 2012) incorporates size of open structure or building in which mechanical ventilation systems are not required for the heat and smoke removal. The UBBL in tenth schedule reveals that; "Open structure is the total area of openings is to be no less than $40 \%$ of the total perimeter wall area enclosing the floor or compartment". The opening(s) should be shaped and located where the total length of the openings has to be more than $50 \%$ of the perimeter of the compartment. The directions of openings are to be opened to outside of building or unenclosed space.

Additionally, the Malaysian Standard (MS:1780) states in basement buildings where the total floor area does not exceed 1000 sq. m., natural smoke ventilation by using smoke vents shall be uniformly distributed to enhance cross ventilation along perimeter of the basement and they shall be easily accessible by fire fighters. The installation can comply with the following requirements; (1) the size of vent openings is not less than $2.5 \%$ of the basement floor area, (2) the smoke vents if covered are breakable/open able from outside of the building in case of fire. On the other hand, for building above ground with floor area exceeds $1000 \mathrm{~m}^{2}$ or the volume exceeds $7000 \mathrm{~m}^{3}$, smoke vents shall be provided at a high level above the smoke layer base. The effective vent openings shall more than 
$2.5 \%$ of the floor area served. The smoke vents shall be of the permanently opened type or open automatically under a fire mode condition without human intervention. Replacement air shall be by means of natural ventilation.

Similar to the UBBL 1984, the Malaysian Standard also allows the use of the window as a smoke ventilator in case of fire. The Malaysian Standard (MS: 1870) Clause 4, sub-clause 4.2, provides that; "smoke removal in a building may be possible by natural means such as openable windows". Nevertheless, there are no explicit requirements incorporated by the regulations concerning on window designs and specifications for smoke ventilation in case of fire. The UBBL 1984 only prescribes design specifications of windows for the purpose of daylighting and ventilation. Clause 39, sub-clause 2 states that; "every room used for the accommodation of patients in a hospital shall be provided with natural lighting and natural ventilation by means of one or more windows having a total area of not less than $15 \%$ of clear floor area of such room and shall have openings capable of allowing a free interrupted passage of air of not less than $10 \%$ of such floor area". Thus, the design of window particularly in hospital wards which is defined by the building code is not for smoke ventilation purposes when fire broke out.

\section{Australia Building Code (BCA 2010) and the Australian Standards (AS 2665)}

Part E2 of the Building Code of Australia (BCA 2010) addresses the importance of smoke management to safeguard building occupants from injury and death caused by fire products including smoke. According to Part E2.1.2.2 and 2.3, smoke management does not apply to small rooms used for short periods of time and open buildings because the smoke and hot gases can vent naturally. A small room will be quickly evacuated before smoke grows up and if the area is only used for short periods, the risk of occupants being exposed to fire is low. Part E2.3 also insists the need for careful consideration and professional judgments using fire safety engineering principles in the application of the smoke hazard management provision for special hazard buildings especially in hospital buildings. In case of natural smoke ventilation design, the building code requires only automatically-opening or permanently-open vents located in roofs complying with AS 2665 to be installed in buildings.

The Australian Standard (AS 2665) sets out the requirements for the design, installation, and commissioning of natural smoke ventilation system. The standard discusses natural smoke ventilation system by means of permanent openings or vents, smoke curtains, and inlet ventilation. The vent openings are to be installed on the roof where a reservoir of smoke can fill the area below the vents. The vents sizes are determined based on the type of fuel load within the building and must be able to withstand rain and wind conditions which may affect their effective operation. They are to be corrosive resistant and maintain the 
Mohd Zaid Ab Ghani \& Srazali Aripin

A Comparative Review of Design Requirements for Natural Smoke Ventilation in Hospital Buildings

structural adequacy as part of the roof structure. Vents are to be designed to ensure that the minimum ratios of the effective aerodynamic area to floor area are within each compartment separated by curtains or walls are met:

3:100 of areas of abnormal fire hazard

2:100 of an area other than an abnormal fire hazard

Areas of 'abnormal' fire hazards include buildings that are involved in the storage or display of goods for sale, making, assembling, altering etc of goods or a process in a laboratory and the building involves materials such as bitumen, cork, enamel, explosives and flammable liquids.

\section{Britain Building Code (2000)}

According to the Approved Document B (ADB), heat and smoke venting are required in a basement. Chapter 19.2 states that "smoke outlets or smoke vents provide a route for heat and smoke to escape to the open air from the basement levels". They can also be used by the fire service to let cooler air into the basements. Sub-clause 19.4 states that "smoke outlets or smoke vents, connected directly to the open air, should be provided from every basement story that has a floor area more than $200 \mathrm{~m} 2$ and more than $3 \mathrm{~m}$ below the adjacent ground level". In case of the deep basement and the amount of external wall is restricted by adjoining buildings, it is acceptable to vent smoke on the perimeter of the basement such as doors. If the basement is compartmented, each compartment should have direct access to venting. The code also does not require providing smoke ventilation system in basement equipped with external doors and windows. As stated in clause 19.6; "Where basements have external doors or windows, the compartment containing the rooms with these doors or windows do not need smoke outlets". In clause 19.7 "Natural smoke outlets should be sited at a high level, either in the ceiling or in the wall of the space they serve. They should be evenly distributed around the perimeter to discharge in the open air outside the building". 19.8 "The combined clear cross-sectional area of all smoke outlets should not be less than 1/40th of the floor area". The building code also requires the smoke outlets or smoke vents not to be placed within means of escape. The general requirements on natural smoke and heat ventilation design above do apply for hospital buildings.

\section{Singapore Building Code}

The code of Buildings Designated for Conservation in Singapore serves to establish the minimum requirements for fire safety provisions. It takes into account the function, design, management, operation, and maintenance of buildings to secure the life safety of occupants in the event of fire. In relation to natural smoke ventilation, the building code prescribes the requirements in basement and other buildings including hospital buildings. 
Clause 7.4.1 (a) states that smoke vents shall be adequately distributed along the perimeter of the basement and their outlets shall be easily accessible during firefighting and rescue operations. The number and their sizes shall be such that the aggregate effective vent openings shall not be less than $2.5 \%$ percent of the basement floor area served. The vent outlets if covered under normal conditions shall be openable in case of fire.

Clause 7.7.1 incorporates the provision of smoke vents having $2.5 \%$ of the floor area shall be provided to the auditorium which is not sprinkler protected and to auditorium having floor area more than $500 \mathrm{~m}^{2}$, if sprinkler protected. The opening of the smoke vents shall be by automatic opening device. The natural smoke ventilation design can be done by using engineered smoke control system.

\section{Comparison of smoke vent's sizes amongst countries}

The comparison of smoke vent's sizes among the four (4) countries is illustrated in Table 1. It can be deduced that the size of smoke vent for natural smoke ventilation system in building which is $2.5 \%$ of floor area is a requirement which can be found in Malaysia, Singapore and Great Britain, meanwhile for Australia is within $2-3 \%$ of floor area. It can also be noticed that Malaysia has set the requirements for the size open façade of the overall façade area through which smoke will naturally ventilated. So, it can be deduced that the size of window opening for natural smoke ventilation design in hospital building should be in the range between $2 \%$ and $3 \%$ of the buildings' floor area.

Table 1: Comparison of requirements for minimal size of openings for smoke ventilation among four countries

\begin{tabular}{|c|c|c|c|c|}
\hline \multirow{3}{*}{ Country } & \multicolumn{2}{|c|}{$\begin{array}{c}\text { Minimal percentage of smoke vent } \\
\text { of floor area }\end{array}$} & \multirow{2}{*}{\multicolumn{2}{|c|}{$\begin{array}{c}\begin{array}{c}\text { Minimal percentage of open } \\
\text { façade }\end{array} \\
\text { Above ground building } \\
\end{array}$}} \\
\hline & \multirow{2}{*}{$\begin{array}{l}\text { Above ground } \\
\text { building }\end{array}$} & \multirow{2}{*}{$\begin{array}{l}\text { Underground } \\
\text { building }\end{array}$} & & \\
\hline & & & $\begin{array}{l}\text { of total façade } \\
\text { per floor }\end{array}$ & of floor area \\
\hline Malaysia & $2.5 \%$ & $2.5 \%$ & $40 \%$ & - \\
\hline Singapore & $\begin{array}{c}2.5 \% \\
\text { (Auditorium) }\end{array}$ & $2.5 \%$ & - & - \\
\hline Australia & $2-3 \%$ & - & - & - \\
\hline Great Britain & $2.5 \%$ & $2.5 \%$ & - & $5 \%$ \\
\hline
\end{tabular}

\section{DISCUSSION AND CONCLUSION}

The paper reports on a comparative review of design requirements for natural smoke ventilation in hospital building. On the basis of the study's objectives, the following are the key findings:

- It can be concluded that there is a requirement for smoke ventilation system in windowless buildings, basement and large buildings where means of escape cannot be achieved within a short period of time. The requirement is 
Mohd Zaid Ab Ghani \& Srazali Aripin

A Comparative Review of Design Requirements for Natural Smoke Ventilation in Hospital Buildings

common to all buildings regardless of their purpose of use and occupancy. The smoke ventilation system is not required to be provided in a small room.

- In hospital building where wards are occupied by patients with limited movement, the provision of smoke ventilation design is relevant and highly important tool to meet The Required Self Egress Time (RSET). This would avoid the precedent fire cases in hospital buildings as highlighted in the literature review above.

- The provision of natural smoke ventilation would play a complimentary role to the required compartmentation in the present building regulations for hospital ward as compartmentation itself may not be sufficient to prevent smoke production and its spread to other enclosures. Therefore, natural smoke ventilation is a significant tool to be appropriately designed and provided in hospital wards in order to extent the required Available Safe Egress Time (ASET).

- The review on the natural smoke ventilation by local and other countries, found that horizontal smoke ventilation can be installed and located at highlevel walls forming like vertical vents in order to exhaust smoke and heat naturally. This would cater for horizontal direction of smoke. The smoke vents (gravity vents) can either be opened position permanently or mechanically designed to open during fire if the smoke vents is closed for security reason

- Although the present building regulations in most countries allow the use of openable windows for the purpose of smoke ventilation, there is no explicitly state the requirements and specifications of the windows used for the smoke and heat ventilation. Based on the study it is obvious that the window sizes and specifications prescribed by UBBL 1984 is solely designed for natural day lighting and ventilation for general building functions. Thus, the windows as openings are in question in terms of its effectiveness to function as natural smoke ventilation.

- Furthermore, the design criteria for smoke ventilation is often specified in terms vent size. Many other design factors for natural smoke ventilation are believed not considered that may influence the performance of the system such as fire size, location and area of opening and external wind effect.

- The design (size, position and specification) of natural smoke ventilation system in a hospital building should not be generalized as applied in other buildings functions where occupied mostly by normal and able-body people.

- Fire engineering approach may be adopted to arrive at appropriate natural smoke venting design for hospital building.

In short, the present study confirms that the present building regulations do not take into account the need for natural smoke ventilation in small rooms and buildings with windows, such as hospital wards. The prescribed size and area of 
windows are merely intended for emission of natural light and air ventilation but not to exhaust smoke. Therefore, appropriate and adequate design for natural smoke ventilation is pertinent for smoke control in hospital wards so that, patients and staff are protected in the event of fire.

\section{ACKNOWLEDGEMENT}

The author would like to express their gratitude to Associate Professor Ar. Dr. Norwina Mohd Nawawi, Dr. Wardah Fatimah Mohammad Yusoff and Dr. Yahya Mohammad Yatim for their constructive comments on this paper.

\section{REFERENCES}

AAMA. (2010). Planning for patient safety. Pediatrics in Review, 847.

Bongiovanni, I., Leo, E., Ritrovato, M., Santoro, A., \& Derrico, P. (2017). Implementation of best practices for emergency response and recovery at a large hospital: A fire emergency case study. Safety Science, 96, 121-131.

Chan, L. M. (2004). Scale modeling of natural vent design and the effects of vent operation time. International Journal on Engineering Performance-Based Fire Codes, 6(4), 272-276.

Chen, H., Liu, N., \& Chow, W. (2009). Wind effects on smoke motion and temperature of ventilation-controlled fire in a two-vent compartment. Building and Environment, 44(12), 2521-2526.

Hui, M. C. (2013). An approach to provide cost effective patient fire safety. Asia Pacific Journal of Health Management, 8(1), 39-44.

Jabatan Bomba dan Penyelamat Malaysia [JBPM] (2017). Statistik kes-kes kebakaran di Malaysia 2010-2016. Pusat Sumber Ibu Pejabat Bomba Malaysia.

Jalali, H., Asl, E., Mehr, A., Pourafzali, S., \& Ghasemi, M. (2016). Prevention and control of operating room fires: Knowledge of staff employed by selected hospitals of Isfahan University of Medical Sciences. Digital Medicine, 2(2), 52.

Ji, J., Gao, Z. H., Fan, C. G., \& Sun, J. H. (2013). Large Eddy Simulation of stack effect on natural smoke exhausting effect in urban road tunnel fires. International Journal of Heat and Mass Transfer, 66, 531-542.

Kerber, S. (2010). Impact of ventilation on fire behavior in legacy and contemporary residential construction. Retrieved from https://ulfirefightersafety.org/researchprojects/impact-of-ventilation-on-fire-behavior-in-legacy-and-contemporaryresidential-construction.html.

Kobes, M., Helsloot, I., Vries, B., \& Post, J. G. (2010). Building safety and human behaviour in fire: A literature review. Fire Safety Journal, 45(1), 1-11.

Krol, M. (2011). Review of smoke management in atrium. Architecture, Civil Engineering, Environment, 3, 121-128.

Kulkarni, R. S., Giri, P. A., \& Gangwal, P. R. (2016). Knowledge and practices regarding 
Mohd Zaid Ab Ghani \& Srazali Aripin

A Comparative Review of Design Requirements for Natural Smoke Ventilation in Hospital Buildings

fire safety amongst health care workers in tertiary care teaching hospital in Marathwada region of Maharashtra, India. International Journal of Community Medicine and Public Health, 3(7), 1900-1904.

Lai, C. M., Chen, C. J., Tsai, M. J., Tsai, M. H., \& Lin, T. H. (2013). Determinations of the fire smoke layer height in a naturally ventilated room. Fire Safety Journal, 58, $1-14$.

Li, S., Su, C., \& Tsai, K. (2016). A study on wind-induced smoke extraction systems for building fires. MATEC Web of Conferences 51, 02001.

Nagral, S. (2012). Fire in a hospital. Indian Journal of Medical Ethics, 9(2), 77-9.

Ong, C., \& Suleiman, M. Z. (2015). Problems in implementation of fire safety management in Malaysia government hospital. Advance of Environmental Biology, 9(March), 47-50.

Pal, I., \& Ghosh, T. (2014). Fire incident at AMRI Hospital, Kolkata ( India ): A real time assessment for urban fire. Journal of Business Management \& Social Sciences Research, 3(1), 9-13.

Partridge, J. J. (2013). Smoke hazard management in Queensland hospitals - A case study (Master research project). University of Canterbury, Christchurch, New Zaeland.

Strating, N. (2013). Evacuation of bedridden building occupants (Final thesis). Eindhoven University of Technology, Eindhoven, the Netherlands.

Su, C., Huang, H., Lin, C., \& Lin, C. (2014). Numerical Simulation of The Impact of Natural Ventilation on Fire Safety in Green Buildings. 2nd Asia Conference of International Building Performance Simulation Association (ASim2014). Nagoya, Japan.

Tancogne-Dejean, M., \& Laclémence, P. (2016). Fire risk perception and building evacuation by vulnerable persons: Points of view of laypersons, fire victims and experts. Fire Safety Journal, 80, 9-19.

Uniform Buildings By-Laws [UBBL] (1984) (Malaysia).

Wegrzynski, W., \& Krajewski, G. (2017). Influence of wind on natural smoke and heat exhaust system performance in fire conditions. Journal of Wind Engineering and Industrial Aerodynamics, 164, 44-53.

Wojciech, W., \& Grzegorz, K. (2017). Combined wind engineering, smoke flow and evacuation analysis for a design of a natural smoke and heat ventilation system. Procedia Engineering, 172, 1243-1251.

Yatim, Y. M. (2009). Fire safety models for high-rise residential buildings in Malaysia (Doctoral thesis). Heriot Watt University, Edinburgh, UK.

Yue, T. K., Chow, W. K., \& Fong, N. K. (2016). Numerical simulation on the effect of natural ventilation to fire growth and the formulation of fire protection strategy for supertall buildings. 